\title{
A Mathematical Model for Color Changes in Red Pepper during Far Infrared Drying
}

\author{
XiaoFeng Ning ${ }^{1}$, ChungSu $\mathrm{Han}^{2}$, $\mathrm{He} \mathrm{Li}^{3 *}$ \\ ${ }^{1}$ Department of Agricultural Mechanization Engineering, Shenyang Agricultural University, Shen-yang, China \\ ${ }^{2}$ Department of Biosystems Engineering, Chungbuk National University, Cheong-ju, Korea \\ ${ }^{3}$ Department of Mechatronics Engineering, Henan Agricultural University, Zheng-zhou, HeNan, China
}

Received: September $26^{\text {th }}, 2012$; Revised: October $25^{\text {th }}, 2012$; Accepted: October $26^{\text {th }}, 2012$

\section{Abstract}

Purpose: The color changes in red pepper during far infrared drying were studied in order to establish a color change model. Methods: The far infrared drying experiments of red pepper were conducted at two temperature levels of $60,70^{\circ} \mathrm{C}$ and two air velocity levels of 0.6 and $0.8 \mathrm{~m} / \mathrm{s}$. The results were compared with the hot-air drying method. The surface color changes parameters of red pepper were measured qualitatively based on L (lightness), a (redness), b (yellowness) and total color changes $(\Delta \mathrm{E})$. The goodness of fit of model was estimated using the coefficient of determination $\left(\mathrm{R}^{2}\right)$, the root mean square error (RMSE), the mean relative percent error $(P)$ and the reduced chi-square $\left(\chi^{2}\right)$. Results: The results show that an increase in drying temperature and air velocity resulted in a decrease in drying time, the values of $\mathbf{L}$ (lightness) and $\mathbf{a}$ (redness) decreased with drying time during far infrared drying. The developed model showed higher $\mathrm{R}^{2}$ values and lower RMSE, $\mathrm{P}$ and $\chi^{2}$ values. Conclusions: The model in this study could be beneficial to describe the color changes of red pepper by far infrared drying.

Keywords: Color changes, Far infrared drying, Mathematical modeling, Red pepper

\section{Introduction}

Pepper (Capsicumitalics annuum L.) is native to Mexico, and has been utilized popularly worldwide. Pepper is a good source of vitamin A and C (Lee et al., 1995), especially vitamins $\mathrm{C}$ content ranks the first among the all green vegetables. Red pepper made by drying and is used to cook various food staffs. It can either be used in industry or medical applications (Isidoro et al., 1995).

The annual consumption of red pepper is 20 million ton and covers $30 \%$ of the total vegetable production in Korea (Jeong et al., 2011). It played a prominent role in Korean foods. Typical drying methods for red pepper are sun drying and hot air drying. Sun drying is the most natural method as it uses sunlight and wind, but it depends

\footnotetext{
*Comesponding author: $\mathrm{He} \mathrm{Li}$

Tel: +86 37163558289; Fax: +86 37163557245

E-mail: chungbuk@sina.com
}

on the weather condition. The drying of red pepper under sun light is risky, because it takes a long time and red pepper is easy to deteriorate and infected with dust insect mold and bacteria. The hot air drying needs a lot of resources for the drying equipment and it entails energy cost (Bae et al., 2003). But the far infrared drying has some advantages over convective hot air drying. Heat transfer coefficients are high, the drying rate is fast and the energy cost is low (Kang et al., 2011). Moreover, drying of agricultural products by far infrared radiation accelerated drying rates and enhanced quality of the dried products (Sakai et al., 1994).

Extensive research efforts have been paid to investigate the drying characteristics or drying models of the red pepper by sun, vinyl house and hot air drying (Yoon and Lee, 2004), microwave-convective drying (Soysal et al., 2009), hot air drying, electrical heater and lamp drying (Kooli et al., 2006). 
A survey of consumer opinions showed that the major factor for deciding the quality of red pepper was color (redness). The red color in pepper represents various carotenoid pigments such as cryptocapsin, capsorubin and capsanthin, which cover $34.7 \%$ of the total pigmentation (Hornero and Minguez, 2001). Therefore the measurement of color is the most important factor to evaluate the drying behaviour of red pepper. However, the studies on the color changes of red pepper are scarce. Therefore, in this work we investigated the effect of far infrared drying temperature and air velocity on drying rate and color changes of red pepper, and to establish the color changes model in order to predict the changes of redness and lightness with time by far infrared drying. Finally we used the coefficient of determination $\left(R^{2}\right)$, the root mean square error (RMSE), the mean relative percent error (P) and the reduced chi-square $\left(\chi^{2}\right)$ to evaluate the goodness of fit of established model.

\section{Materials and Methods}

\section{Materials}

The red peppers used in this study were obtained from Chongwon-Gun of Korea, during the summer season. Red peppers were stored in storage at $5{ }^{\circ} \mathrm{C}$ until conducting the experiments. The length, diameter and weight of red peppers were 13 15 cm, 2.0 2.4 cm and 13 15 g, respectively. The initial moisture content was $80.5 \sim 82.6 \%$ on a wet base $(\mathrm{wb})$ and the initial color values were $28.45 \sim$ 32.33 (L-lightness), 36.06 41.97 (a-redness) and 26.53 28.55 (b-yellowness).

\section{Experimental apparatus}

The schematic diagram of the experimental apparatus is shown in Figure 1.The dimension of the dryer that used in this experiment was $5500 \times 1800 \times 900 \mathrm{~mm}(\mathrm{~L} \times \mathrm{H} \times \mathrm{W})$. The dryer was composed of far infrared heater (MEP550 , Restoration, Korea), drying chamber $(\mathrm{L} \times \mathrm{H} \times \mathrm{W}, 5340 \times$ $620 \times 90$ ), belt conveyer, blast fan (DTB-402, Dongkun, Korea), control panel which can control the temperature of far infrared heater, belt speed and air velocity. Another dryer (Model BOPP-1.5, Shinheung Co., Korea) was also used for hot air drying experiment.

\section{Experimental methods}

Based on the result of our preliminary experiment, the far infrared drying test was conducted at the drying temperatures of $60^{\circ} \mathrm{C}$ and $70^{\circ} \mathrm{C}$ with air velocities of 0.6 and $0.8 \mathrm{~m} / \mathrm{s}$. For comparative analysis, the hot air drying temperatures were maintained at $70^{\circ} \mathrm{C}$ (dry-bulb temperature) and $60^{\circ} \mathrm{C}$ (wet-bulb temperature) for $6 \mathrm{~h}$, and $55^{\circ} \mathrm{C}$ (dry-bulb temperature) and $35^{\circ} \mathrm{C}$ (wet-bulb temperature) for $18 \mathrm{~h}$. Approximately $10 \mathrm{~kg}$ sample of red pepper was used for each drying condition, and dried until the final moisture content reached at $17 \pm 0.5 \%$ (wb).

\section{Analysis \\ Drying rate}

The initial moisture content was measured with the air-oven method. Twenty grams of randomly selected samples were taken and dried in an experimental dryer (WFO-600ND, Tokyo Ri-kakai, Japan) at the temperature of $105^{\circ} \mathrm{C}$ for $24 \mathrm{~h}$, and the moisture content was determined from the ratio of the weight changes before and after drying.

The drying rate was represented by the moisture ratio (MR). For determination of moisture ratio, the moisture content was measured at each time and converted into the moisture ratio by using Equation (1) and (2) (Henderson and Perry, 1976; Li et al., 2009).

$$
\begin{aligned}
& M R=\frac{M_{t}-M_{e}}{M_{o}-M_{e}} \\
& M_{e}=\frac{M_{0} \cdot M_{f}-M_{m}}{M_{0}+M_{f}-2 M_{m}}
\end{aligned}
$$

where $M R$ is moisture ratio, $M_{e}, M_{0}, M_{m}, M_{f}$ are equilibrium, initial, middle and final moisture content, respectively. Since the $M_{e}$ is relatively smaller than that of $M_{t}$ or $M_{0}$, for calculate accurately, the moisture ratio (MR) was calculated by $\left(M_{t^{-}} M_{e}\right) /\left(M_{0}-M_{e}\right)$.

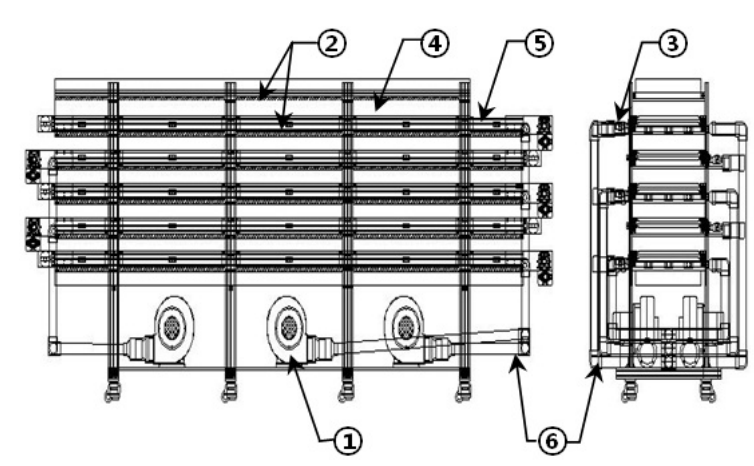

Figure 1. Schematic diagram of a far infrared dryer: (1) Blast fan, (2) Far infrared heater, (3) Motor, (4) Drying chamber, (5) Belt conveyer, (6) Blast pipe. 


\section{Color measurement}

The surface colors of both fresh and dried red peppers were measured by a colorimeter (JX777, C.T.S. Co, Tokyo, Japan), based on lightness (L) [black (0) to light (100)], redness (a) [red (60) to green (-60)] and yellowness (b) [yellow (60) to blue (-60)] values from four parts of the red pepper body, and measurements were individually taken for six samples once every hour while drying. The colorimetric initial correct values of $\mathrm{L}$, a and $\mathrm{b}$ were 98.81 , 0.08 and 0.06 , respectively. Before and after the drying, the total color differences $(\Delta \mathrm{E})$ were determined using the following equation (Lopez-malo et al., 1998; Li, 2009; Lee et al., 2010):

$$
\Delta \mathrm{E}=\sqrt{\Delta \mathrm{L}^{2}+\Delta \mathrm{a}^{2}+\Delta \mathrm{b}^{2}}
$$

where, $\Delta \mathrm{E}$ is the total color difference, $\Delta \mathrm{L}, \Delta \mathrm{a}$ and $\Delta \mathrm{b}$ are the changes of lightness, redness and yellowness before and after drying.

\section{Drying modeling}

According to the drying time, greater variations of lightness and redness of red pepper were observed. Therefore, SAS RSQUARE PRCO was used to establish a suitable model for describing the lightness and redness changes of red pepper. The model constants were determined by coefficient of determination $\left(\mathrm{R}^{2}\right)$. The established model can be described as follows:

$$
\frac{\mathrm{L}(\mathrm{a})_{\mathrm{t}}}{\mathrm{L}(\mathrm{a})_{0}}=\mathrm{A}-\frac{\mathrm{B}}{\mathrm{t}+\mathrm{C}}+\mathrm{D} \cdot \exp (-\mathrm{E} \cdot \mathrm{t})
$$

where $L(a)_{t}$ was the lightness or redness at any drying time $\mathrm{t}, \mathrm{L}(\mathrm{a})_{0}$ was the initial value of lightness or redness, $\mathrm{t}$ was the drying time; A, B, C, D and E were model constants. The ratio of current values to initial ones were fitted into the above model.

The equation (5) was used to calculate the model constants. The equation is the functions of drying temperature and air velocity and the constants $\left(\mathrm{a}_{0}, \mathrm{a}_{1}, \mathrm{a}_{2}, \mathrm{a}_{3}, \mathrm{a}_{4}\right.$ and a5) were determined by SAS PROC STEPWISE. This model represents combined effect of the drying parameters such as drying temperature and air velocity.

$$
\begin{aligned}
& \text { A, B, C, D, E }=a_{0}+a_{1} \cdot(T)+a_{2} \cdot(A V)+a_{3} \cdot(T)^{2}+ \\
& a_{4} \cdot(A V)^{2}+a_{5} \cdot(T \cdot A V)
\end{aligned}
$$

where $\mathrm{T}$ is drying temperature, $\mathrm{AV}$ is air velocity. The goodness of fit of the model was evaluated using the coefficient of determination $\left(\mathrm{R}^{2}\right)$, the root mean square error (RMSE), the mean relative percent error $(\mathrm{P})$ and the reduced chi-square $\left(\chi^{2}\right)$. In general, the higher the values of $\mathrm{R}^{2}$ and the lower the values of RMSE, $P$ and $\chi^{2}$, the better goodness of fit. These parameters can be calculated as follows:

$$
\begin{aligned}
& \mathrm{R}^{2}=\frac{\sum_{\mathrm{i}=1}^{\mathrm{N}}\left(\mathrm{MR}_{\text {exp }, \mathrm{i}}-\mathrm{MR}_{\text {exp,ave }}\right)^{2}-\sum_{\mathrm{i}=1}^{\mathrm{N}}\left(\mathrm{MR}_{\text {exp, } \mathrm{i}}-\mathrm{MR}_{\mathrm{pre}, \mathrm{i}}\right)^{2}}{\sum_{\mathrm{i}=1}^{\mathrm{N}}\left(\mathrm{MR}_{\text {exp }, \mathrm{i}}-\mathrm{MR}_{\text {exp }, \text { ave }}\right)^{2}} \\
& \operatorname{RMSE}=\left[\frac{1}{\mathrm{~N}} \sum_{\mathrm{i}=1}^{\mathrm{N}}\left(\mathrm{MR}_{\text {exp }, \mathrm{i}}-\mathrm{MR}_{\mathrm{pre}, \mathrm{i}}\right)\right]^{1 / 2} \\
& \mathrm{P}=\frac{100}{\mathrm{~N}} \sum_{\mathrm{i}=1}^{\mathrm{N}} \frac{\left|\left(\mathrm{MR}_{\text {exp }, \mathrm{i}}-\mathrm{MR}_{\text {pre }, \mathrm{i}}\right)\right|}{\mathrm{MR}_{\text {exp }, \mathrm{i}}} \\
& \chi^{2}=\frac{\sum_{\mathrm{i}=1}^{\mathrm{N}}\left(\mathrm{MR}_{\mathrm{exp}, \mathrm{i}}-\mathrm{MR}_{\mathrm{pre}, \mathrm{i}}\right)^{2}}{\mathrm{~N}-\mathrm{n}}
\end{aligned}
$$

where $\mathrm{MR}_{\text {exp }}$ is the experimental moisture ratio, $\mathrm{MR}_{\mathrm{pre}}$ is the predicted moisture ratio, $\mathrm{N}$ is the number of observations and $n$ is the number of costants (Toğrul, 2005).

\section{Statistical analysis}

The experiments was triplicate, and its average value was used for statistical analysis, being conducted by SAS version 8.2. The mean differences of experimental values were determined by Duncan's multiple range test using analysis of variance (one-way ANOVA) with a significant level of 0.05 .

\section{Result and Discussion}

\section{The changes of moisture content and moisture ratio with drying temperature and time}

The variations of moisture content and moisture ratio with drying time are shown in Figure 2 . At $60{ }^{\circ} \mathrm{C}$, the drying time of red pepper at air velocity of 0.6 and $0.8 \mathrm{~m} / \mathrm{s}$ were 18 and $17 \mathrm{~h}$, respectively. When temperature was increased at $70^{\circ} \mathrm{C}$, the drying time changes to 14 and $12 \mathrm{~h}$ for the same air velocity, respectively. There was an inverse relationship between drying temperature and drying time, and air velocity and drying time. Suggesting that with an increase in drying temperature and air velocity resulted in a decrease in drying time, which is probably due to the increase of heat transfer between the air and the red pepper, and the acceleration of water migration inside them (Sacilik and Elicin, 2006). The effect of temperature 

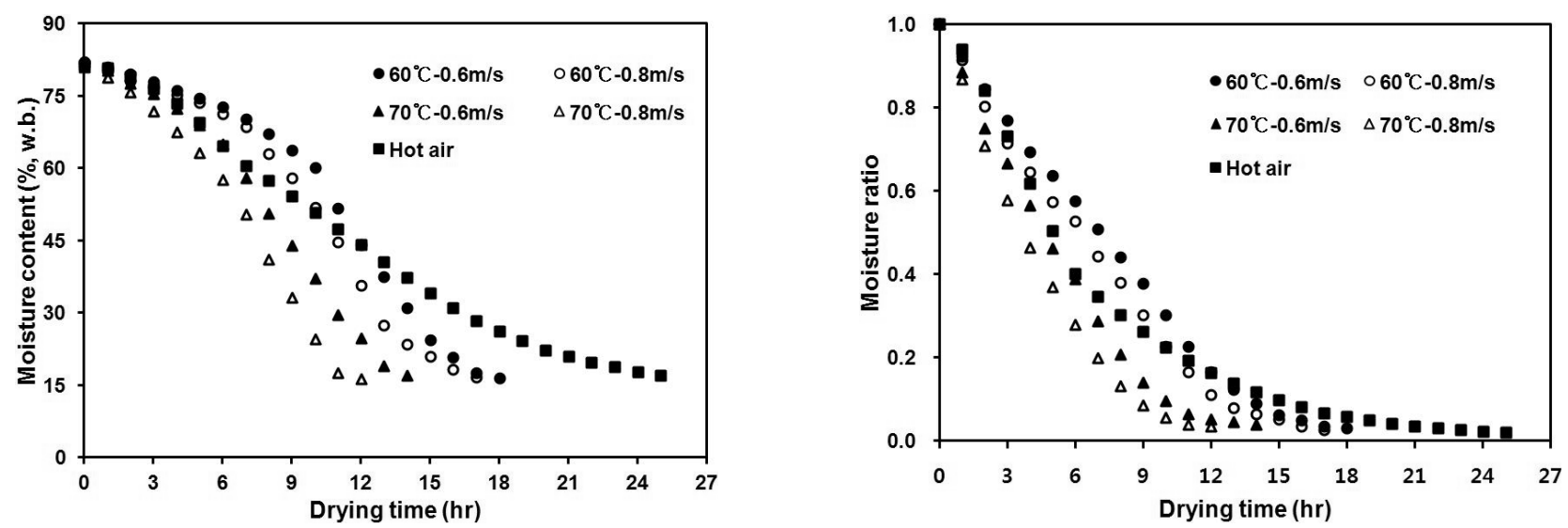

Figure 2. Effect of drying temperature on moisture content and moisture ratio.

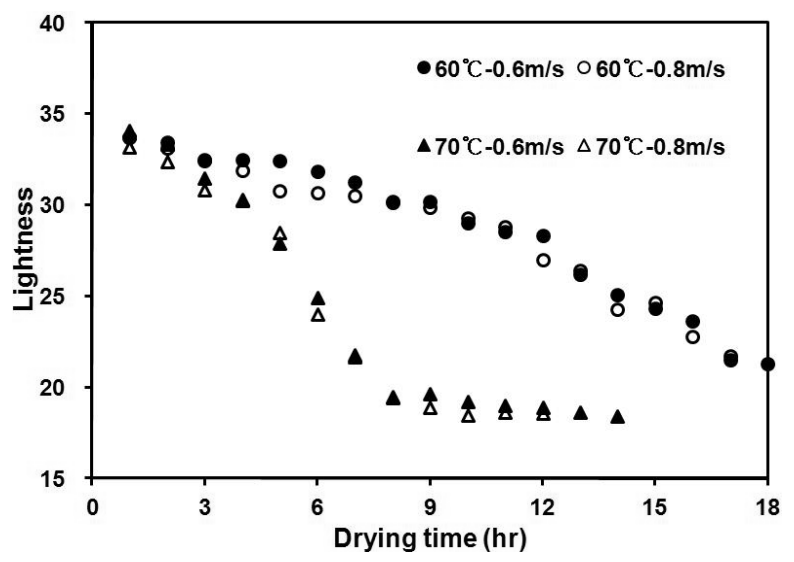

(a) Lightness

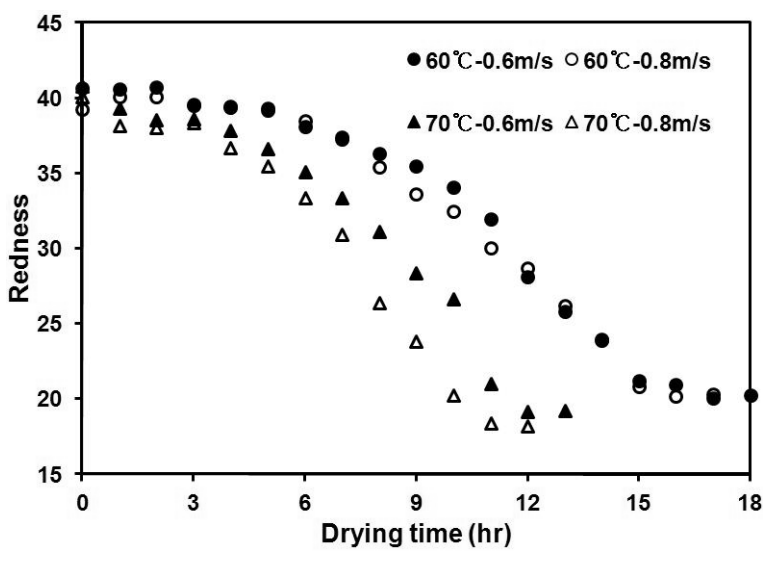

(b) Redness

Figure 3. Changes of lightness and redness with drying time.

and air velocity on drying rate is extensively investigated by Lee et al., (2011). In addition, the hot air drying time was $25 \mathrm{~h}$, which is significantly longer than far infrared drying. That is due to higher far infrared radiant energy and heat conductivity that enhances the moisture diffusion rate of red pepper.

\section{Color changes}

The variations of lightness and redness with drying time are shown in Figure 3 (a) and (b). The results showed that lightness and redness of red pepper tended to decrease with drying time. The initial lightness values at the drying temperature of $60^{\circ} \mathrm{C}$ with an air velocities of $0.6,0.8 \mathrm{~m} / \mathrm{s}$ were 33.71 and 33.70 , respectively. The end lightness values were 21.27 and 21.73 , which were lower than 12.44 and 11.97 from the initial values at the same drying conditions. At the drying temperature of $70^{\circ} \mathrm{C}$, the lightness values were decreased by a big margin at the drying time of 5 to $8 \mathrm{~h}$, along with a small change at the late drying stage. The decreasing trend of redness showed different from one of lightness. The redness of red pepper sharply decreased at the drying times of 5 to $8 \mathrm{~h}$ at the drying temperatures of $70^{\circ} \mathrm{C}$. The moisture content also decreased substantially (from $70 \%$ to $30 \%$ ) at the same drying time. Apart from this it can be suggested that the changes of moisture content have a significant effect on the changes of surface color. It has been suggested that the high color values of agricultural products are closely associated with high water content (Vega et al., 2007)

Figure 4 shows the $\Delta \mathrm{E}$ values of red pepper at different drying conditions. The changes of $\Delta \mathrm{E}$ values showed increasing trend with increasing drying temperature. The values of $\Delta \mathrm{E}$ changes from 28.45 to 32.73 at the drying temperatures of 60 and $70^{\circ} \mathrm{C}$, respectively. The similar results were also reported by Li et al., (2009), where high values of $\Delta \mathrm{E}$ were associated with high drying temperatures; the higher the drying temperature made the pigments instable. For the hot air drying, $\Delta \mathrm{E}$ value was a litter higher 


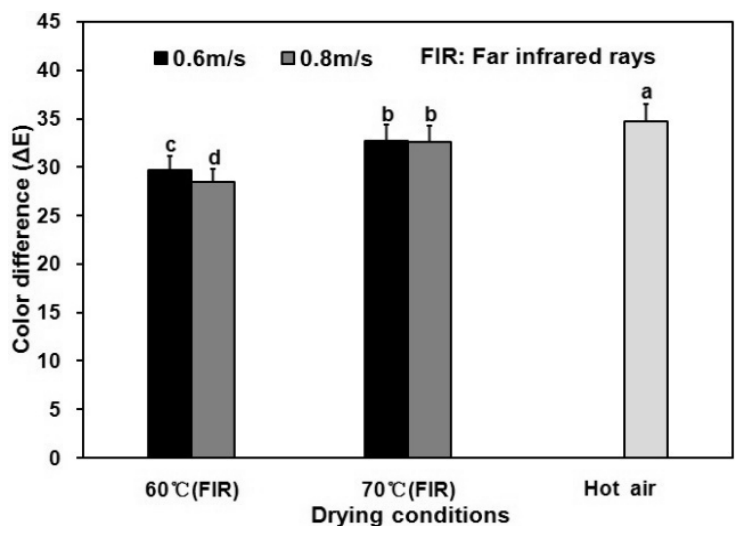

Figure 4. Comparison of color difference of red pepper by drying conditions. Means with different letters are significantly different by Duncan's multiple range test $(p<0.05)$. The vertical bars represent the standard error of three replicates.

than far infrared drying.

\section{Fitting of the color change curves}

In order to predict the color changes of red pepper, the model constants values were obtained against those of the drying temperature (T) and air velocity (AV) using SAS multiple regression analysis. The constants and $\mathrm{R}^{2}$ values of lightness and redness were shown in Tables 1 and 2. Both of the lightness and redness model constants were written as a function of drying temperature. The drying temperature showed significant effect on the color change of red pepper in far infrared drying. The effects of some drying parameters related to the drying conditions such as material size, drying temperature, relative humidity, etc. were reported by Özdemir and Devres (1999). The

Table 1. Estimated values of model constants for lightness

\begin{tabular}{rl} 
Model constants & $\mathrm{R}^{2}$ \\
$\mathrm{~A}=-3.70705-0.05811 \times \mathrm{T}$ & 0.8746 \\
$\mathrm{~B}=-144.52180+2.03441 \times \mathrm{T}$ & 0.9958 \\
$\mathrm{C}=48.3389+2.03441 \times \mathrm{T}$ & 0.9939 \\
$\mathrm{D}=-0.79959-0.0002629 \times \mathrm{T}^{2}$ & 0.9728 \\
$\mathrm{E}=-6.28340-0.10812 \times \mathrm{T}$ & 0.9857 \\
\hline
\end{tabular}

lightness model constants showed higher $\mathrm{R}^{2}$ values than redness model, ranging from the values of 0.5133 to 0.9777 .

Accordingly, the lightness and redness of red pepper at any time during far infrared drying process can be estimated using following equations. $L_{t}, a_{t}$ were the lightness and redness at any drying time $t$, respectively. $L_{0}$, $a_{0}$ were the initial value of lightness and redness, respectively.

$$
\begin{aligned}
& \frac{\mathrm{L}_{\mathrm{t}}}{\mathrm{L}_{0}}=(-3.70705-0.05811 \times \mathrm{T})-\frac{-144.52180+2.03441 \times \mathrm{T}}{\mathrm{t}+48.3389+2.03441 \times \mathrm{T}} \\
& +(-0.79959-0.00026296 \times \mathrm{T}) \cdot \exp [-(-6.28340-0.10812 \times \mathrm{T}) \cdot \mathrm{t}] \\
& \frac{\mathrm{a}_{\mathrm{t}}}{\mathrm{a}_{0}}=\left(-1.39041-0.00017481 \times \mathrm{T}^{2}\right)-\frac{-403.31274+91.08649 \times \ln \mathrm{T}}{\mathrm{t}+75.95496-16.98324 \times \ln \mathrm{T}} \\
& +(-8.31311+1.30865 \times \ln \mathrm{T}) \cdot \exp [-(-0.54955+0.0136 \times \mathrm{T}) \cdot \mathrm{t}]
\end{aligned}
$$

Tables 3 and 4 show the results of statistical analysis of the model fitted to the drying date. In all the cases of drying conditions, the $\mathrm{R}^{2}$, RMSE, $\mathrm{P}$ and $\chi^{2}$ values varied between 0.9624 0.9919, 0.0122 0.0447, 1.13 4.91\% and $0.55 \times 10^{-3} \sim 2.50 \times 10^{-3}$, respectively. Based on the parameters $\left(\mathrm{R}^{2}, \mathrm{RMSE}, \mathrm{P}\right.$ and $\left.\chi^{2}\right)$ the model at $60^{\circ} \mathrm{C}$ showed a better agreement between the predicted and experimental values than the model at $70{ }^{\circ} \mathrm{C}$.

The variations of experimental and predicted values at drying temperatures of $60,70^{\circ} \mathrm{C}$ and air velocities of 0.6 , $0.8 \mathrm{~m} / \mathrm{s}$ for lightness and redness are given in Figure 5 . Results showed that the model provides a good agreement between the predicted and the experimental values at the drying temperatures of $60^{\circ} \mathrm{C}$ and $70^{\circ} \mathrm{C}$. However, drying at later stage, the model showed a little difference between the predicted and the experimental values. Thus the

Table 3. Statistical analysis of the model fitted to the drying data for lightness

\begin{tabular}{cccccc} 
Drying conditions & $\mathrm{R}^{2}$ & $\mathrm{RMSE}$ & $\mathrm{P}(\%)$ & $\chi^{2}\left(10^{-3}\right)$ \\
$60^{\circ} \mathrm{C}-0.6 \mathrm{~m} / \mathrm{s}$ & 0.9815 & 0.0277 & 1.13 & 0.17 \\
$60^{\circ} \mathrm{C}-0.8 \mathrm{~m} / \mathrm{s}$ & 0.9884 & 0.0217 & 1.66 & 0.38 \\
$70^{\circ} \mathrm{C}-0.6 \mathrm{~m} / \mathrm{s}$ & 0.9705 & 0.0387 & 2.19 & 0.48 \\
$70^{\circ} \mathrm{C}-0.8 \mathrm{~m} / \mathrm{s}$ & 0.9624 & 0.0447 & 2.42 & 0.90 \\
\hline
\end{tabular}


Table 4. Statistical analysis of the model fitted to the drying data for redness

\begin{tabular}{ccccc} 
Drying conditions & $\mathrm{R}^{2}$ & $\mathrm{RMSE}$ & $\mathrm{P}(\%)$ & $\chi^{2}\left(10^{-3}\right)$ \\
\hline $60^{\circ} \mathrm{C}-0.6 \mathrm{~m} / \mathrm{s}$ & 0.9919 & 0.0122 & 2.95 & 0.88 \\
$60^{\circ} \mathrm{C}-0.8 \mathrm{~m} / \mathrm{s}$ & 0.9782 & 0.0182 & 2.30 & 0.55 \\
$70^{\circ} \mathrm{C}-0.6 \mathrm{~m} / \mathrm{s}$ & 0.9746 & 0.0304 & 3.97 & 1.78 \\
$70^{\circ} \mathrm{C}-0.8 \mathrm{~m} / \mathrm{s}$ & 0.9686 & 0.0351 & 4.91 & 2.50 \\
\hline
\end{tabular}
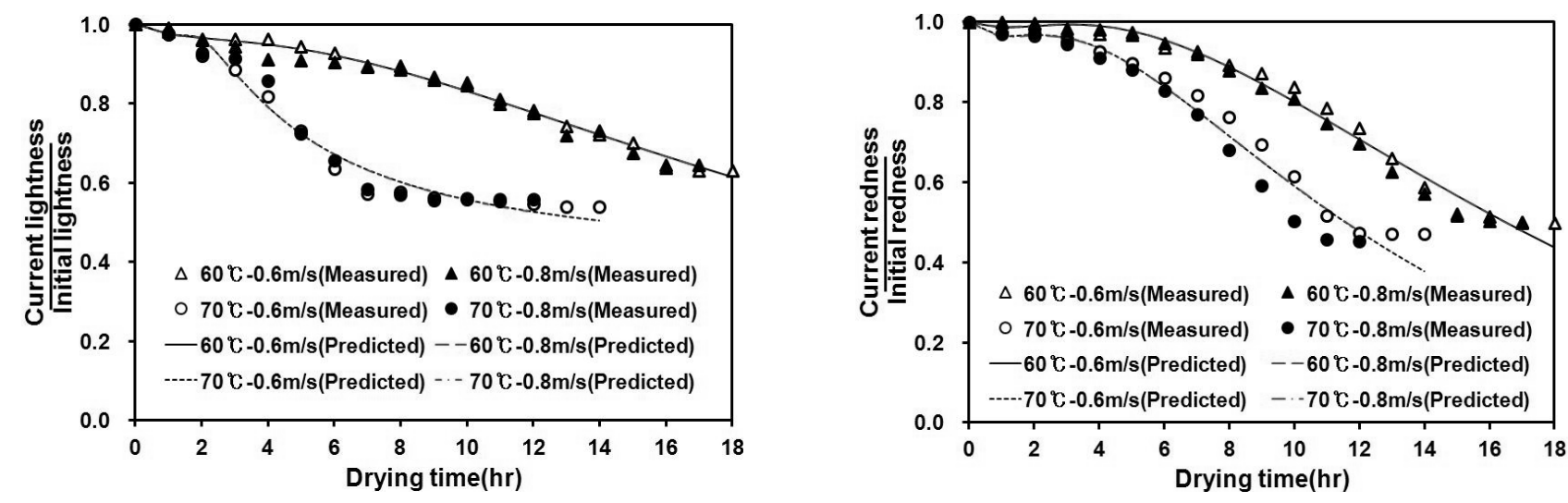

Figure 5. Variation of experimental and predicted data.

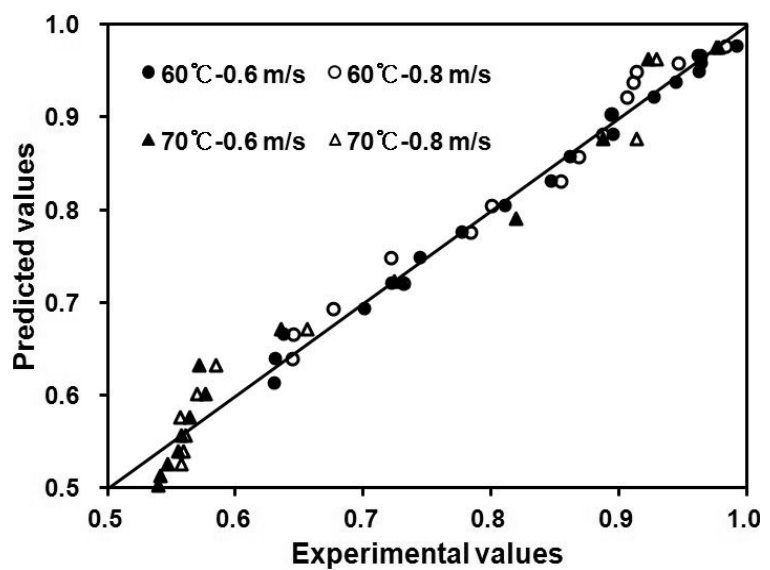

(a) Lightness

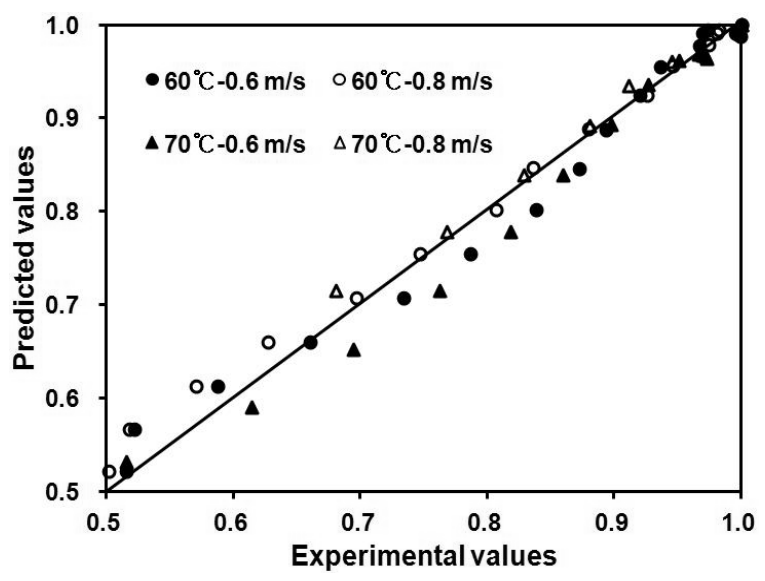

(b) Redness

Figure 6. Comparison of experimental and predicted data.

developed model can make better predictions about lightness and redness at the far infrared drying times up to 16 $\mathrm{h}$ and $12 \mathrm{~h}$ for the drying temperatures of 60 and $70^{\circ} \mathrm{C}$, respectively.

Figure 6 (a) and (b) show the comparison between predicted and experimental values at various drying conditions. The developed established color model provides a good agreement between the experimental and predicted values; there is strong evidence of linearity between experimental values and predicted ones.

\section{Conclusions}

The far infrared drying characteristics of red pepper was evaluated at temperatures of 60 and $70^{\circ} \mathrm{C}$ with two air velocities of 0.6 and $0.8 \mathrm{~m} / \mathrm{s}$. The results were compared with the hot-air drying method. The goodness of fit of the developed color model were evaluated using the coefficient of determination $\left(\mathrm{R}^{2}\right)$, the root mean square error (RMSE), mean relative deviation modulus (P) and the reduced chi-square $\left(\chi^{2}\right)$. The results showed that the drying rate of far infrared drying was $7 \sim 13 \mathrm{~h}$ faster than 
that of hot air drying at the same drying conditions. The effect of drying temperature on the changes of lightness and redness of red pepper was also studied. The model established here showed high value for the coefficient of determination $\left(\mathrm{R}^{2}\right)(0.9624 \sim 0.9919)$ and low values for the root mean square error (RMSE) (0.0122 0.0447), mean relative percent error $(\mathrm{P})(1.13 \sim 4.91)$ and reduced chi-square $\left(\chi^{2}\right)(0.17 \sim 2.50)$. The model is thought to be a suitable model for describing the color changing behavior of red pepper during far infrared drying. The developed model can be beneficial to investigate the color changes behaviour of other fruits and vegetable.

\section{Conflict of Interest}

No potential conflict of interest relevant to this article was reported

\section{Acknowledgement}

We appreciate the Korea institute of planning and evaluation for technology in food, agriculture, forestry and fisheries for financial support and encouraging us to attempt this study.

\section{References}

Bae, N. K., J. B. Lee and H. S. Sang. 2003. Drying Characteristics of red peppers by infrared heating. Journal of Korean Society of Industrial Application 6:65-71. (In Korean)

Henderson, S. M. and R. L. Perry. 1976. Agricultural Process Engineering, Westport, AVI Publishing Company. Inc. USA.

Hornero-Mendez, D. R. and M. I. Minguez-Mpsquera. 2001. Rapid spectrophoto metric determination of red and yellow iso-chromic carotenoid fractions in paprika and red pepper oleoresins. Journal of Agricultural and Food Chemistry 49:3584-3588.

Jeong, J. W., O. S. Kim and J. M. Sung. 2011. Quality and fermentation characteristics of kimchimade with different types of dried red pepper (Capscicum annum L.). Journal of Food Science Nutrition 16:74-82.

Kang, T. H., H. K. Hong, H. Y. Jeon and C. S. Han. 2011.
Drying characteristics of squids according to farinfrared and heated air drying conditions. Journal of Biosystems Engineering 36:109-115.

Kooli, S., A. Fadhel, A. Farhat and A. Belghith. 2006. Drying of red pepper in open sun and greenhouse conditions Mathematical modeling and experimental validation. Journal of Food Engineering 79:1094-1103.

Lee, S. K., W. Kim, H. Kim and J. W. Han. 2011. Determination of boxthorn drying conditions and using agricultural dryer. Journal of Biosystems Engineeering 36(4):273-278.(In Korean)

Lee, S. K., W. J. Park, M. H. Kang and S. W. Paik. 2010. Analysis of the drying characteristics of Lyciifructus with drying plates. Journal of Biosystems Engineeering 35(4):250-256.(In Korean)

Lee, Y., L. R. Howard and B. Villalon. 1995. Flavonoids and antioxidant activity of fresh pepper (Capsicum annuum) after hot-ir dying. Journal of Food Science 60(6):12691276.

Isidoro, E., D. J. Cotter, G. C. Fernandez and G. M. Southward. 1995. Color retention in red chile powder as related to delayed harvest. Journal of Food Science 60(5): 1075-1077.

Li, H. 2009. Drying and quality characteristics of agricultural and fishery products using far-infrared rays. (Thesis PhD.), ChungBuk National University, Cheongju, South Korea.

Li, H.,T. H. Kang, X. F. Ning, S. C. Cho and C. S. Han. 2009. Far infrared Rays Drying Characteristics of Tissue Cultured Mountain Ginseng Roots. Journal of Biosystems Engineering 34(3):175-182.

Lopez-malo, A., E. Palou, G. V. Barbosa-canovas, J. WeltiChanes and B. G. Swanson. 1998. Polyphenoloxidase activity and color changes during storage of high hydrostatic pressure treated avocado puree. Food Research International 31(8):549-556.

Özdemir, M. and Y. O. Devres. 1999. The thin layer drying characteristics of hazelnuts during roasting. Journal of Food Engineering 42:225-233.

Sacilik, K. and A. K. Elicin. 2006. The thin layer drying characteristics of organic apple slices. Journal of Food Engineering 73:281-289.

Sakai, C. and T. Hanzawa.1994. Application and advances in far infrared heating in Japan. Trends in Food Science and Technology 5(11):357-362.

Soysal, Y., Z. Ayhan and O. Estürk. 2009. Intermittent microwave-convective drying of red pepper: Drying 
kinetics, physical (color and texture) and sensory quality. Biosystems Engineering 103:455-463.

Toğrul, H. 2005. Suitable drying model for infrared drying of carrot. Journal of Food Engineering 77: 610-619.

Vega, A., P. Fito, A. Andrés and R. Lemus. 2007. Mathematical modeling of hot-air drying kinetics of red bell pepper (var. Lamuyo). Journal of Food Engineering 79:14601466.

Yoon, W. M. and J. Y. Lee. 2004. Effect of Drying Method on the Fruit and Powder Color of Red Pepper. Journal of Natural Sciences 15:97-109. 